\title{
Assessing the Effectiveness and Efficiency of the Public Service Budget
}

\author{
Dendy Syaiful Akbar ${ }^{1}$, Dini Yuliani ${ }^{1}$, Aan Anwar Sihabudin ${ }^{1}$, Purnama Sari ${ }^{1}$ \\ \{dendysyaiful1984@gmail.com\} \\ Universitas Galuh Ciamis $^{1}$
}

\begin{abstract}
Public services by local governments will not be separated from the use of the budget. The budget must be used effectively and efficiently so that it is expected to improve services to the public continuously. The purpose of this study is to assess the effectiveness and efficiency of public service budgets in local governments. The research method used is a descriptive method with a quantitative approach. The level of effectiveness is measured by comparing the target with the realization of the public service budget. The public service budget is one component of regional spending. While the level of efficiency is measured by comparing the public service budget of regional spending. The results of the study show that the majority of public service budgets have been used effectively and very efficiently, even though in a period of time there is less efficient budget usage.
\end{abstract}

Keywords: Effectiveness, Efficiency, Public Service Budget, Local Government

\section{Introduction}

The administration of the regional government cannot be separated from the use of the budget. Every year the local government plans a budget or known as the local government budget [1]. In the local government budget structure, there is a budget for public services which consists of personnel expenditure, goods, and services expenditure. It is expected that the budget can be realized effectively and efficiently so that it can improve the quality of service to the public. Escalante and Fernandez explained that conceptually, public services are a series of activities designed to benefit users during a period [2].

The implementation of decentralization and regional autonomy in Indonesia still does not meet expectations. There are still many problems related to the performance of local governments in public services, such as not optimal efforts to improve the economy and development in the regions [3]. For this reason, local governments are required to build good performance measures. Performance is measured through the use of performance measurements where a matrix is used to quantify the efficiency and effectiveness of activity [4].

Research conducted on rural special budgeting in the European Union is based on an objectively measured index of rural development. The results showed that the development budget was focused on underdeveloped villages which were dominated by agricultural areas. It is proven that this approach is effective to improve public services in rural areas [5]. From several countries in the world have successfully implemented digital public services. They use public budgets to develop digital public services. Finally, countries that have successfully 
implemented digital public services received an award from the United Nations [6]. Research conducted in Thailand found results that regional authorities did not attempt to increase public goods and services spending, because government resources increased. This condition is due to very weak accountability in using the budget, where social capital and citizen participation can improve the accountability and performance of the public sector [7].

Thus the importance of knowing the implementation of local government budgets in providing services to the public, the aim of this study is to analyze the effectiveness and efficiency of public service budgets in a local government. The measurement is carried out as a form of public participation to participate in supervising the use of local government budgets. The results of the study are intended to provide information to local governments to be able to use public service budgets effectively and efficiently.

\section{Methodology}

This research uses the descriptive method with a quantitative approach. The method is used to explain phenomena or characteristics regarding the effectiveness and efficiency of public service budgets analyzed using data in the form of numbers. The study was conducted to the local government of Ciamis Regency through the Local Government Financial Office as an institution that manages finance and parties that provide research data. The period of measurement year is for five years, namely in the 2013-2017 budget year.

Data to measure the effectiveness of public service budgets is taken from the budget structure for public services or direct expenditure, which consists of personnel expenditure and goods and services expenditure. Direct expenditure is the expenditure of the local government to finance activity activities that are directly related to the productivity of the government apparatus for the achievement of organizational goals, for example, such as spending on employee honorarium in an activity. Measurement of the effectiveness of public service budgets is measured using the following formula:

\section{Effectiveness $\quad=\frac{\text { Direct Expenditure Realization }}{\text { Direct Expenditure Target }}$}

Using this formula it is assumed that effectiveness will be seen from the achievement of the direct budget. For this reason, the calculation is done by comparing the realization of the budget target. To determine the level of effectiveness of the public service budget, the results of the calculation will be compared with the following table-1:

\begin{tabular}{c|c} 
Level of Effectiveness & Criteria \\
\hline$>100 \%$ & Very Effective \\
$86 \%-100 \%$ & Effective \\
$71 \%-85 \%$ & Less Effective \\
$56 \%-70 \%$ & Ineffective \\
$<55 \%$ & Very Ineffective
\end{tabular}

Meanwhile, data for measuring budget efficiency for public services is taken from the structure of regional expenditure, which consists of indirect expenditure and direct expenditure. Indirect expenditures are expenditures that are indirectly related to productivity or organizational goals, for example, such as spending on salaries of employees, although not working, still have to be paid. Measurement of the effectiveness of public service budgets is measured using the following formula: 


\section{Efficiency $=\frac{\text { Direct Expenditure Realization }}{\text { Regional Expenditure Realization }}$}

Using this formula it is assumed that efficiency will compare the amount of direct expenditure realization and the total realization of regional expenditure. To determine the level of efficiency of public service budgets, the calculation results will be compared with the following table-2:

\begin{tabular}{c|c} 
Level of Efficiency & Criteria \\
\hline$>100 \%$ & Very Inefficient \\
$86 \%-100 \%$ & Inefficient \\
$71 \%-85 \%$ & Less Efficient \\
$56 \%-70 \%$ & Efficient \\
$<55 \%$ & Very Efficient
\end{tabular}

After analyzing the level of effectiveness and efficiency of public service budgets, the next step is to explain the matter so that at the final stage a conclusion can be drawn from the results of the study.

\section{Result and Discussion}

Table-3 illustrates the target and realization of Ciamis District expenditure in the 20132017 fiscal year:

Table-3: Target and Realization of Ciamis District Expenditures for 2013-2017 Budget Year (millions of IDR)

\begin{tabular}{crrrccc}
\multirow{2}{*}{ Year } & \multicolumn{3}{c}{ Direct Expenditure } & \multicolumn{3}{c}{ Local Expenditure } \\
\cline { 2 - 7 } & \multicolumn{1}{c}{ Target } & Realization & \% & Target & Realization & \% \\
\hline 2013 & $742,686.25$ & $667,704.69$ & 89.90 & $2,359,736.63$ & $2,184,752.02$ & 92.58 \\
2014 & $721,068.65$ & $650,780.29$ & 90.25 & $2,126,411.91$ & $2,007,151.40$ & 94.39 \\
2015 & $994,084.98$ & $896,493.68$ & 90.18 & $2,487,203.72$ & $2,319,078.15$ & 93.24 \\
2016 & $974,543.86$ & $915,911.97$ & 93.98 & $2,647,585.76$ & $2,460,806.67$ & 92.95 \\
2017 & $1,607,449.00$ & $1,536,229.83$ & 95.57 & $2,232,802.56$ & $2,126,678.56$ & 95.25 \\
\hline
\end{tabular}

Based on table-3, it can be seen that the realization of direct expenditure and regional expenditure reaches an average of $90 \%$. Direct expenditure is one component of regional expenditure that is used for direct public service activities. During the 2013-2017 budget year, direct expenditure realization experienced ups and downs. In 2013 the budget realization amounted to IDR667,704.69 million from the targeted amount of IDR742,686.25 million or reached $89.90 \%$. In 2014 the budget realization increased to IDR650,780.29 million from the targeted IDR721,068.65 million or reached 90.25\%. In 2015 the realization of the budget decreased compared to the previous year but was not significant. Budget realization in that year amounted to IDR896,495.68 million, of which the target was IDR994,084.98 million or reached $90.18 \%$. In 2016 the realization of the budget again increased to IDR915,911.97 
million from the targeted IDR974,543.86 million or reached 93.98\%. In 2017 was the highest realization of the budget which amounted to IDR1,536,229.83 million from the targeted target of IDR1,607,449.00 million or $95.57 \%$ reached. In that year the local government of the Ciamis Regency raised the direct expenditure budget with the aim of improving the quality of public services.

As with direct spending, the realization of regional expenditure during the 2013-2017 fiscal year experienced ups and downs. Regional expenditures represent the total budget of the regional government in implementing government affairs, including direct expenditure. In 2013, the budget realization amounted to IDR2,184,752.02 million from the targeted target of IDR2,359,736.63 million or $92.58 \%$ reached. In 2014 the realization of the budget increased to IDR2,007,151.40 million from the target of IDR2,126,411.91 million or reached $94.39 \%$. In 2015 the realization of the budget fell to $93.24 \%$, of which the realization of the budget amounted to IDR2,319,078.15 million which was targeted at IDR2,487,203.72 million. In 2016 the realization of the budget fell again to $92.95 \%$. Budget realization amounted to IDR2,460,806.67 million from the targeted target of IDR2,647,585.76 million. The 2017 budget realization rose to $95.25 \%$. Budget realization amounted to IDR2,126,678.56 million from the target of IDR2,232,802.56 million.

Every year both the realization of direct expenditure and regional expenditures are not achieved $100 \%$. This condition could be due to several programs that were not resolved, but the numbers were not too many. This can be seen from the achievement of the budget which reached an average of more than $90 \%$. The other reason could be that the local government would make efficiency on the budget. But efficiency cannot provide assurance that the program can be run effectively. For this reason, measurement is needed to determine the level of effectiveness and efficiency associated with the use of the public service budget.

From table-3 can be calculated the level of effectiveness and efficiency of public service budget Ciamis Regency during the 2013-2017 fiscal year. The effectiveness of the public service budget is calculated by comparing the realization of the budget target. Table- 4 is the result of calculating the effectiveness level of the public service budget:

Table-4: The Effectiveness Level of Ciamis District Public Service Budget 2013-2017 Fiscal Year (millions of IDR)

\begin{tabular}{lccccc}
\multicolumn{1}{c}{ Year } & $\mathbf{2 0 1 3}$ & $\mathbf{2 0 1 4}$ & $\mathbf{2 0 1 5}$ & $\mathbf{2 0 1 6}$ & $\mathbf{2 0 1 7}$ \\
\hline Realization & $667,704.69$ & $650,780.29$ & $896,493.68$ & $915,911.97$ & $1,536,229.83$ \\
Target & $742,686.25$ & $721,068.65$ & $994,084.98$ & $974,543.86$ & $1,607,449.00$ \\
Level of & & & & & \\
Effectiveness & 89.90 & 90.25 & 90.18 & 95.57 & 95.57 \\
$(\%)$ & Effective & Effective & Effective & Effective & Effective \\
Criteria & & & & & \\
\hline
\end{tabular}

Based on table-4, it can be explained that the Ciamis District public service budget for the 2013-2017 fiscal year is on the effective criteria (table-1). This condition is due to the realization of direct expenditure almost always reaching the budget target. This is proof that the local government has effectively used the public service budget. The regional government optimizes service to the public after the release of the Pangandaran District into the New Autonomous Region in 2012. The effort was carried out as evidence that performance-based budgeting has been carried out by the local government. 
Almost every year the realization of public service budgets is always increasing. This is evidence that efforts to improve the quality of public services continue to be improved by local governments. Only one period of budget realization has decreased, namely in 2014. However, in the following year, the increase in the amount of realization continued. The local government continues to strive for the public service budget to be used effectively. The effectiveness of the use of the budget can be seen from the amount of the budget realized, if the budget achievement is close to $100 \%$ it is considered effective, but if it is more than $100 \%$ it is considered very effective. This means that the implementation of government programs in public services has been completed during a period.

For the regional government, the implementation of regional autonomy is currently required to be able to create a management system that is able to support regional development and improve the quality of public services. In this case, the regional budget becomes the main policy instrument for local governments and is an important point in the development of regional effectiveness and capability. Another function is as a tool for determining the amount of income and expenditure and assisting in decision making.

Not only effectiveness but efficiency in the use of the budget is also proof of the management of a good budgeting system. Measurement of the level of budget efficiency of public services is done by comparing the realization of direct expenditure with the realization of regional expenditure. Table-5 is the result of the calculation of the level of efficiency of the budget of the public service of the Ciamis District Government in the 2013-2017 fiscal year:

Table-5: Efficiency Level of Ciamis District Public Services for 2013-2017 Fiscal Year (millions of IDR)

\begin{tabular}{lccccc}
\multicolumn{1}{c}{ Year } & $\mathbf{2 0 1 3}$ & $\mathbf{2 0 1 4}$ & $\mathbf{2 0 1 5}$ & $\mathbf{2 0 1 6}$ & $\mathbf{2 0 1 7}$ \\
\hline $\begin{array}{l}\text { Direct } \\
\text { Expenditure } \\
\text { Realization }\end{array}$ & $667,704.69$ & $650,780.29$ & $896,493.68$ & $915,911.97$ & $1,536,229.83$ \\
$\begin{array}{l}\text { Local } \\
\text { Expenditure } \\
\text { Realization }\end{array}$ & $2,184,752.02$ & $2,007,151.40$ & $2,319,078.15$ & $2,460,806.67$ & $2,126,678.56$ \\
\hline $\begin{array}{l}\text { Level of } \\
\text { Efficiency }\end{array}$ & 30.56 & 32.42 & 38.66 & 37.22 & 72.24 \\
\hline & Very & & Very & Very & Less \\
Criteria & Efficient & Very Efficient & Efficient & Efficient & Efficient
\end{tabular}

Based on table-5, it can be explained that the public service budget or direct expenditure of the Ciamis District government in the 2013-2016 fiscal year is on very efficient criteria (table2 ). This condition is caused by the amount of direct expenditure realization which is much lower than the total regional expenditure. From 2013 to 2016 the realization of direct expenditure was only $30 \%$ more than the total regional expenditure. But in the 2017 budget year, the public service budget used is less efficient (table-2). Almost more than $70 \%$ of regional expenditure is spent on improving services to the public. Although in that year there was a decrease in the efficiency of public service budgets, the implementation of the budget was effectively used by the local government.

Almost every year during 2013-2016 the local government pays attention to the efficient use of the budget for public services. This shows that the budget management system has been carried out well. Budget efficiency does not mean that the quality of program implementation 
must be reduced, but the regional government strives to avoid waste so that it will have more budget left over. The remaining budget can be used to improve the public service system or be used to improve quality. The efficiency of the use of public service budgets can be seen from the amount of the direct expenditure budget for total regional expenditure. If the amount of direct expenditure is less than 55\% of the total regional expenditure, it is considered very efficient. This means that the local government has set a minimum budget possible but the achievement of maximum results.

The efficiency of the budget for the local government is the minimum use of the budget with the desired results. But it is not easy to realize, an optimal budget management system is needed. The control system for budget use is also the right support for accountability to be realized. The participation of all interested parties is needed to participate in the supervision of the use of public budgets to be more effective and efficient.

\section{Conclusion}

The Ciamis District government public service budget during the 2013-2017 fiscal year has been used effectively. This condition is evidenced by the realization of the direct expenditure budget which reached an average of $90 \%$ more. Almost every year the realization of the public service budget continues to increase. This condition proves that the local government continues to improve the quality of public services. Meanwhile in terms of efficiency during the 2013-2016 fiscal year, the budget for public services has been used very efficiently. This means that the local government has used the minimum budget to achieve maximum results. But in the 2017 budget year, the public service budget is used less efficiently. That happens because almost $70 \%$ of regional spending is used for direct expenditure or total spending is focused on public services.

\section{References}

[1] M. Rampengan, G. B. Nangoi, and H. Manossoh, “Analisis Efektivitas dan Efisiensi Pelaksanaan Anggaran Belanja Badan Perencanaan Pembangunan Daerah (Bappeda) Kota Manado,” J. Berk. Ilm. Efisiensi, vol. 16, no. 3, pp. 616-623, 2016.

[2] E. F. G. Escalante and L. F. P. Fernandez, "Preparing Transitions in Public Services: Payoff Dimension, Value Estimation, Schedule and Budget Computation," Socioecon. Plann. Sci., vol. 55, pp. 36-46, 2016.

[3] C. K. Waney, D. P. Saerang, and S. W. Alexander, "Analisis Realisasi Anggaran Untuk Menilai Efektivitas dan Efisiensi Kinerja Pemerintah di Dinas Pertanian dan Peternakan Provinsi Sulawesi Utara," J. Ris. Akunt. Going Concern, vol. 13, no. 2, p. 334, 2018.

[4] J. R. Matthews, “Assessing Organizational Effectiveness : The Role of Performance Measures," Libr. Q., vol. 81, no. 1, pp. 83-110, 2011.

[5] E. Kiryluk-Dryjska and P. Beba, "Region-Specific Budgeting of Rural Development Funds-An Application Study," Land use policy, vol. 77, pp. 126-134, 2018.

[6] J. Bertot, E. Estevez, and T. Janowski, "Universal and Contextualized Public Services: Digital Public Service Innovation Framework.," Gov. Inf. Q., vol. 33, no. 2, pp. 211222, 2016.

[7] P. Suebvises, "Social Capital, Citizen Participation in Public Administration, and Public Sector Performance in Thailand," World Dev., vol. 109, pp. 236-248, 2018. 